\title{
PENERAPAN PEMBELAJARAN KOOPERATIF MODEL GROUP INVESTIGATION (GI) PADA POKOK BAHASAN SIFAT DALAM PERUBAHAN KIMIA DAN FISIKA KELAS VII DI MTS SAYYID YUSUF KECAMATAN TALANGO
}

\author{
Herowati $^{1}$, Nisfil Maghfiroh Meita ${ }^{2}$ \\ FKIP Universitas Wiraraja Sumenep ${ }^{1,2}$ \\ heromukmin@yahoo.co.id ${ }^{1}$, nisfilmeita35@gmail.com ${ }^{2}$
}

\begin{abstract}
ABSTRAK
Penelitian ini bertujuan untuk untuk menerapkan pembelajaran kooperatif model Group Investigation (GI), sebagai suatu upaya perbaikan dan peningkatan proses pembelajaran. Metode penelitian menggunakan Penelitian Tindakan Kelas yang dilaksanakan dengan mengikuti prosedur penelitian berdasarkan pada prinsip Kemmis S, MC Toggar R (1988) yang mencakup kegiatan perencanaan (planning), tindakan (action), observasi (observation), refleksi (reflection) atau evaluasi. Keempat kegiatan ini berlangsung secara berulang dalam bentuk siklus. Penelitian ini dilakukan dengan cara berkolaborasi antara dosen FKIP Prodi Pendidikan IPA dengan guru bidang studi IPA kelas VII MTs Sayyid Yusuf Kecamatan Talango. Subyek penelitian ini adalah siswa kelas VII yang berjumlah 35 siswa. Teknik pengumpulan data yang digunakan adalah observasi, wawancara, tes, catatan lapangan dan dokumentasi. Sedangkan analisis data meliputi reduksi data, paparan data, dan penarikan kesimpulan.

Hasil penelitian menunjukkan bahwa (1) kinerja belajar siswa meningkat setelah pembelajaran IPA menggunakan pembelajaran kooperatif model Group Investigation (GI). Siswa sangat antusias membahas topik dalam diskusi, dan berusaha menjawab dan menemukan informasi tentang topik tersebut. Siswa saling berebut mengemukakan informasi (apa yang mereka ketahui) tentang topik. Setelah dilakukan pembagian tugas, kelompok siswa bekerja sesuai dengan tugasnya masing-masing; (2) prestasi belajar siswa dari aspek kognitif mengalami peningkatan sebesar 11,16. Pada siklus pertama nilai rata-rata siswa adalah 69,44 dan meningkat pada siklus kedua menjadi 80,60. Sedangkan hasil belajar siswa dari aspek afektif juga mengalami peningkatan sebesar 13,9. Pada siklus pertama nilai rata-rata siswa sebesar 68,57 meningkat menjadi 82,47 pada siklus kedua; (3) hambatan yang muncul dalam penerapan pembelajaran kooperatif Group Investigation (GI) yaitu (a) siswa belum terbiasa belajar dengan pembelajaran kooperatif Group Investigation (GI) sehingga guru bidang studi IPA masih kesulitan dalam merangsang siswa untuk aktif; (b) keterbatasan waktu dalam pelaksanaan penelitian; (c) minimnya sarana dan prasarana yang mendukung proses pembelajaran kooperatif Group Investigation (GI) khususnya. Berdasarkan nilai yang diperoleh siswa dapat disimpulkan bahwa pembelajaran kooperatif model Group Investigation (GI), dapat digunakan pada penelitian tindakan kelas.
\end{abstract}

Kata Kunci: pembelajaran kooperatif, Group Investigation (GI), penelitian tindakan kelas, hasil belajar.

\section{PENDAHULUAN}

Meningkatkan mutu pendidikan adalah menjadi tanggungjawab semua pihak yang terlibat dalam pendidikan terutama bagi guru. Guru adalah orang yang paling berperan dalam menciptakan sumber daya manusia yang berkualitas yang dapat bersaing di zaman pesatnya perkembangan teknologi. Dalam setiap pembelajaran guru selalu menggunakan pendekatan, strategi dan metode pembelajaran yang dapat memudahkan siswa memahami materi yang diajarkannya, namun masih sering 
terdenggar keluhan dari para guru di lapangan tentang materi pelajaran yang terlalu banyak dan keluhan kekurangan waktu untuk mengajarkannya semua.

Menurut pengamatan peneliti, dalam pelaksanaan pembelajaran di kelas penggunaan model pembelajaran yang bervariatif masih sangat rendah dan guru cenderung menggunakan model konvesional pada setiap pembelajaran yang dilakukannya. Hal ini mungkin disebabkan kurangnya penguasaan guru terhadap model-model pembelajaran yang ada, padahal penguasaan terhadap model-model pembelajaran sangat diperlukan untuk meningkatkan kemampuan profesional guru, dan sangat sesuai dengan kurikulum berbasis kompetensi.

Upaya peningkatan kualitas pendidikan di antarnya adalah penyempurnaan KBK (Kurikulum berbasis kompetensi) menjadi KTSP (Kurikulum Tingkat Satuan Pendidikan) yang kemudian disempuranakan lagi menjadi kurikulum 2013 yang mulai diberlakukan di sekolah menengah pertama bertujuan untuk menghasilkan lulusan yang kompeten dan berkualitas sehingga dapat melanjutkan pendidikan ke jenjang yang lebih tinggi. Hal ini hanya dapat tercapai apabila proses pembelajaran yang berlangsung mampu mengembangkan seluruh potensi siswa dan terlibat langsung didalamnya, seperti dalam pembelajaran IPA yang lebih menekankan praktik keilmuan daripada teori.

Disamping itu dengan penyempurnaan kurikulum tersebut memberi kemudahan kepada guru dalam menyajikan pengalaman belajar, sesuai dengan prinsip belajar yang mengacu pada empat pilar pendidikan universal, yaitu belajar untuk mengetahui (learning to know), belajar dengan melakukan (learning to do), belajar untuk hidup dalam kebersamaan (learning to live together), dan belajar menjadi diri sendiri (learning to be).

Untuk itu guru perlu meningkatkan mutu pembelajarannya, dimulai dengan rancangan pembelajaran yang baik dengan memperhatikan tujuan, karakteristik siswa, materi yang diajarkan, dan sumber belajar yang tersedia. Kenyataannya masih banyak ditemui proses pembelajaran yang kurang berkualitas, tidak efisien dan kurang mempunyai daya tarik, bahkan cenderung membosankan, sehingga hasil belajar yang dicapai tidak optimal. Hal ini bisa dilihat dari hasil belajar IPA siswa kelas VII MTs Sayyid Yusuf Kecamatan Talango yang dipaparkan sbb:

Tabel 1. Nilai Ulangan untuk Mata Pelajaran IPA Kelas VII Semester 1 Tahun Ajaran 2013/ 2014 MTs Sayyid Yusuf Kecamatan Talango.

\begin{tabular}{|c|c|c|c|}
\hline Ulangan ke & Nilai Tertinggi & Nilai Terendah & Nilai Rata-Rata \\
\hline 1 & 7,26 & 4,26 & 5,76 \\
\hline 2 & 7,12 & 4,12 & 5,62 \\
\hline
\end{tabular}

Rendahnya perolehan hasil belajar mata pelajaran IPA di MTs Sayyid Yusuf Kecamatan Talango menunjukkan adanya indikasi terhadap rendahnya kinerja belajar siswa dan kemampuan guru dalam mengelola pembelajaran yang berkualitas. Untuk mengetahui mengapa prestasi siswa tidak seperti yang diharapkan, tentu guru perlu merefleksi diri untuk dapat mengetahui faktor-faktor penyebab ketidak berhasilan siswa dalam pelajaran IPA. Sebagai guru yang baik dan profesional, permasalahan ini tentu perlu ditanggulangi dengan segera. Berdasarkan hal tersebut, penerapan pembelajaran koopertif model Group Investigation (GI) menjadi alternatif untuk dapat meningkatkan prestasi belajar siswa dalam mata pelajaran IPA. 
Penelitian ini dilakukan peneliti yang bertugas sebagai tenaga dosen FKIP-Universitas Wiraraja Sumenep berkolaborasi dengan guru IPA MTs Sayyid Yusuf Kecamatan Talango. Disamping itu kolaborasi ini dapat meningkatkan kemampuan guru dalam berlolaborasi ini, diharapkan kemampuan profesional guru dalam merancang model pembelajaran akan lebih baik lagi dan dapat menerapkan model pembelajaran yang lebih bervariatif merefleksi diri terhadap kinerja yang telah dilakukannya, sehingga dapat melakukan perubahan dan perbaikan kualitas pembelajaran dan mengelola proses pembelajaran yang lebih terpusat pada siswa.

Model pembelajaran Group Investigation (GI) adalah salah satu model pembelajaran kooperatif dalam proses pembelajaran "siswa bersama dengan kelompokkanya melakukan upaya untuk menyelesaikan masalah yang mereka hadapi, sumber apa yang mereka butuhkan, siapa yang akan melakukan, dan bagaimana mereka akan menampilkan tugas mereka yang sudah selesai ke hadapan kelas" (Slavin: 2008:216). Sehingga dalam proses pembelajaran kooperatif model Group Investigation (GI) ini, biasanya ada pembagian tugas dalam kelompok di antara anggota kelompok. Dengan cara seperti itu siswa atau anak menjadi kritis dan aktif belajar.

Berdasarkan latar belakang permasalahan di atas maka rumusan masalah pada penelitian ini adalah sebagaimana di bawah ini.

1. Bagaimana penerapan pembelajaran kooperatif model Group nvestigation (GI) pada pokok bahasan sifat dalam perubahan kimia dan fisika?

2. Bagaimana kinerja belajar siswa dalam pembelajaran kooperatif Group Investigation (GI)?

3. Bagaimana kreativitas siswa dalam pembelajaran kooperatif Group Investigation (GI)
4. Bagaimana hasil belajar siswa setelah mengikuti pembelajaran kooperatif Group Investigation (GI) pada pokok bahasan sifat dalam perubahan kimia dan fisika?

5. Apakah hambatan-hambatan yang muncul selama diterapkannya Group Investigation (GI)?

\section{METODE PENELITIAN}

a. Jenis Penelitian

Penelitian ini merupakan penelitian tindakan kelas (Classroom Action Reseach) yang dilaksanakan dengan mengikuti prosedur penelitian berdasarkan pada prinsip Kemmis S, MC Toggar R (1988) yang mencakup kegiatan perencanaan (planning), tindakan (action), observasi (observation), refleksi (reflection) atau evaluasi. Keempat kegiatan ini berlangsung secara berulang dalam bentuk siklus. Tujuan penelitian ini untuk menerapkan model pembelajaran Group Investigation (GI) sebagai suatu upaya perbaikan dan peningkatan proses pembelajaran serta upaya meningkatkan hasil belajar siswa kelas VII MTs Sayyid Yusuf Talango.

b. Prosedur Penelitian

Penelitian Tindakan Kelas ini terdiri atas dua siklus kegiatan sebagai berikut.

SIKLUS 1

Tahap Perencanaan (Planning)

1. Mengidentifikasi masalah

2. Menganalisis dan merumuskan masalah

3. Merancang pembelajaran kooperatif model Group Investigation (GI)

4. Mendiskusikan penerapan pembelajaran kooperatif model Group Investigation (GI).

5. Menyiapkan instrumen (angket, pedoman observasi, tes akhir)

6. Menyusun kelompok belajar siswa

7. Merencanakan tugas kelompok 
Tahap Melakukan Tindakan (Action)

1. Melaksanakan langkah-langkah sesuai perencanaan

2. Menerapkan pembelajaran kooperatif model Group Investigation $(\mathrm{GI})$

3. Melakukan pengamatan terhadap setiap langkah-langkah kegiatan sesuai rencana

4. Memperhatikan alokasi waktu yang ada dengan banyaknya kegiatan yang dilaksanakan

5. Mengantisipasi dengan melakukan solusi apabila menemui kendala saat melakukan tahap tindakan

Tahap Mengamati (observasi)

1. Melakukan diskusi dengan guru IPA MTs Sayyid Yusuf dan kepala Sekolah untuk rencana observasi.

2. Melakukan pengamatan terhadap penerapan pembelajaran kooperatif model Group Investigation (GI) yang dilakukan guru IPA kelas VII.

3. Mencatat setiap kegiatan dan perubahan yang terjadi saat penerapan model pembelajaran kooperatif model Group Investigation (GI).

4. Melakukan diskusi dengan guru untuk membahas tentang kelamahan-kelemahan atau kekurangan yang dilakukan guru serta memberikan saran perbaikan untuk pembelajaran berikutnya

Tahap refleksi (Reflection)

1. Menganalisis temuan saat melakukan observasi pelaksanaan observasi

2. Menganalisis kelemahan dan keberhasilan guru saat menerapkan pembelajaran kooperatif model Group Investigation (GI) dan mempertimbangkan langkah selanjutnya

3. Melakukan refleksi terhadap penerapan pembelajaran kooperatif model Group Investigation (GI).

4. Melakukan refleksi terhadap kreativitas siswa dalam pembelajaran IPA
5. Melakukan refleksi terhadap hasil belajar siswa

\section{SIKLUS II}

Tahap Refleksi/Siklus II meliputi

Tahap Perencanaan (Planning)

1. Hasil refleksi dievaluasi, didiskusikan, dan mencari upaya perbaikan untuk diterapkan pada pembelajaran berikutnya.

2. Mendata masalah dan kendala yang dihadapi saat pembelajaran

3. Merancang perbaikan II berdasarkan refleksi siklus I

Tahap Melakukan Tindakan (Action)

1. Melakukan analisis pemecahan masalah

2. Melaksanakan tindakan perbaikan II dengan memaksimalkan penerapan pembelajaran kooperatif model Group Investigation (GI).

Tahap Mengamati (observation)

1. Melakukan pengamatan terhadap penerapan pembelajaran kooperatif model Group Investigation (GI)

2. Mencatat perubahan yang terjadi

3. Melakukan diskusi membahas masalah yang dihadapi saat pembelajaran dan memberikan balikan.

Tahap Refleksi (Reflection)

1. Merefleksi proses pembelajaran kooperatif model Group Investigation (GI).

2. Merfleksi hasil belajar siswa dengan penerapan pembelajaran kooperatif model Group Investigation (GI).

3. Menganalisis temuan dan hasil akhir penelitian

4. Rekomendasi

Dari tahap kegiatan pada siklus I dan II, hasil yang diharapkan adalah:

1) Siswa memiliki kemampuan dan kreativitas serta selalu aktif terlibat dalam proses pembelajaran IPA pada pokok bahasan sifat dalam perubahan kimia dan fisika.

2) Guru memiliki kemampuan merancang dan menerapkan 
pembelajaran kooperatif model Group Investigation (GI) pada mata pelajaran IPA pokok bahasan sifat dalam perubahan kimia dan fisika.

3) Terjadi peningkatan prestasi siswa pada mata pelajaran IPA

\section{c. Teknik Analisis Data}

Teknik analisis data pada penelitian ini bersifat kualitatif sebagaimana hakikat PTK. Namun data-data kuantitatif tidak berarti diabaikan, akan tetapi digunakan sebagai pelengkap dalam melakukan analisis kualitatif.

\section{PEMBAHASAN}

\section{Penerapan Pembelajaran Ko- operatif Model Group Investigation (GI) Mata pelajaran IPA pokok bahasan sifat dan perubahan kimia dan fisika zat.}

\section{Siklus I}

Sebelum guru melaksanakan tahap awal berdasarkan langkah-langkah pernbelajaran model Group Investigation (GI), terlebih dahulu guru menjelaskan kompetensi dasar dan indikator pada pokok bahasan yang akan dipelajari oleh siswa pada pokok bahasan perubahan sifat kimia dan fisika zat. Kemudian guru memberikan pre test kepada siswa, siswa terlihat kurang suka karena mereka tidak terbiasa mengerjakan soal pre tes terlebih dahulu sebelum pelajaran dimulai bahkan sebagian ada yang malas untuk mengerjakannya. Selanjutnya, guru menjelaskan rencana kegiatan pembelajaran kooperatif model Group Investigation (GI) sehingga semua siswa dapat mengetahui bagaimana prosedur dan langkah-langkah dalam pembelajaran model Group Investigation (GI).

Langkah selanjutnya adalah melaksanakan tahap awal dalam pembelajaran model Group Investigation (GI) yaitu mengidentitikasi topik dan mengatur murid ke dalam kelompok. Guru membagi kelas yang berjumlah 30 siswa menjadi 5 kelompok secara heterogen. masing-masing kelompok terdiri 6 orang. Lalu guru membantu siswa menyiapkan sarana dan prasarana. Tiap kelompok memilih sub topik tersebut sesuai dengan minat, kemudian guru menjelaskan tugas kelompok beserta tanggung jawabnya dan terus memotivasi siswa agar semangat dan aktif selama proses pembelajaran.

Pada tahap 2. siswa merencanakan kerjasama dalam menyelesaikan tugas. dengan merencanakan investigasi atau merencanakan kerjasama dalam menyelesaikan tugas maka setiap anggota kelompok dapat mengetahui masalah yang akan dipelajarinya. Tahap mi merupakan bagian penting untuk melibatkan setiap anggota kelompok dalam menyelesaikan tugas. Jika masingmasing anggota kelompok sudah mempunyai bagian tugas, maka tugas tersebut dapat dikerjakan secara bersamasama dan saling membantu sehingga dapat mpermudah dan mempercepat penyelesaian tugas. berdasarkan fakta pada siklus I hanya sedikit kelompok yang sudah melaksanakan kerjasama dengan membuat pembagian tugas sedangkan kelompok lain tidak melakukan pembagian tugas bahkan masih bingung. Hal ini mungkin disebabkan karena sebagian siswa masih belum mengerti tentang langkah-langkah dalam pembelajaran model Group Investigation (GI).

Tahap ketiga yaitu melaksanakan investigasi. Dalam tahap ini setiap kelompok melaksanakan rencana kerjasama dalam menyelesaikan tugas yang telah dibuat pada tahap 2. Tindakan yang dilakukan oleh setiap kelompok selama investigasi adalah mencani materi, mengumpulkan informasi, menganalisis ifogmasi, dan mendiskusikan informasi yang telah diperoleh tersebut serta membuat kesimpulan-kesimpulan untuk dijadikan sebagai pemecahan masalah. Tetapi pada kenyataannva memang tidak sesuai dengan yang diharapkan oleh peneliti. Ada berapa siswa yang mendominasi 
pekerjaan dan ada juga siswa yang hanya diam bahkan mengobrol dengan temannya sehingga membuat kelas menjadi ramai.

Pada tahap 4 setiap kelompok menyiapkan atau membuat laporan yang akan dipresentasikan di depan kelas. Selain itu. masing-masing kelompok juga merencanakan bagaimana nantinya mempresentasikan hasil dan diskusi mereka di depan kelas. Sementara guru memeriksa laporan akhir yang dibuat oleh masing-masing kelompok.

Tahap selanjutnya yaitu mempresentasikan laporan akhir. Pada tahap 5 ini. masing-masing kelompok mempresentasikan hasil kerja kelompoknya. Sementara guru hanya memfasilitatori kegiatan presentasi siswa di depan kelas sedangkan siswa dan kelompok lain mendengarkan presentasi dengan seksarna. Faktanya pada tahap ini setiap kelompok mempresentasikan laporan hasil kerjanya dengan kaku dan hanya membacakan laporannya tanpa memaharni isinya dengan waktu yang singkat. Setelah presentasi selesai. siswa diberikan sempatan untuk mengajukan pertanyaan. memberikan kritik. Saran, masukan atau tanggapan. Namun pada kenyataannya hanya ada beberapa siswa yang aktif sedangkan siswa yang lain hanya diam. Padahal guru sudah berusaha memberikan sempatan dan motivasi. Hal itu disebabkan karena siswa tidak terbiasa dengan pembelajaran model Group Investigation (GI) sehingga siswa tidak mempunyai beranian dan kepercavaan diri untuk bertanya dan mengeluarkan ide atau pendapatnya. Tahap terakhir adalah tahap evaluasi. Sebelum melakukan evaluasi guru memberikan post test kepada siswa.

Pada tahap akhir siklus 1 guru berikan penilaian bahwa saat pembagian kelompok siswa sebaiknya dapat menerima siapapun yang menjadi anggota kelompoknya dan saat pemilihan sub topik sebaiknya siswa dapat saling berbagi sub topik sesuai dengan minatnya. Guru juga memberikan penilaian pada saat siswa rencanakan kerja sama dalam menyelesaikan tugas dan melaksanakan investigasi. Guru menilai bahwa ada beberapa kelompok belum dapat membuat bagian tugas secara jelas sehingga ada siswa yang mendominasi pekerjaan, ada siswa yang hanya diam saja.

Penilaian selanjutnya adalah saat kelompok mempresentasikan laporannya guru menilai bahwa presentasi yang dilakukan kurang maksimal dimana siswa masih terlihat kurang percaya diri belum mengerti serta memahami dengan baik isi laporarmya. Selain itu pada saat diskusi berlangsung peneliti menilai bahwa siswa rnasih banyak yang pasif hanya sedikit siswa yang aktif untuk itu peneliti mengharapkan agar siswa lebih aktif lagi saat diskusi pada siklus II. Tidak hanya memberikan penilaian tapi guru juga memberikan kesimpulan dan semua materi yang telah dipresentasikan oleh siswa. Dengan adanya kesimpulan tersebut, maka diharapkan pertanyaan yang diajukan oleh siswa dapat diketahui jawabannya dengan jelas dan bisa dimengerti oleh semua siswa. Kemudian guru juga memberikan evaluasi pencapaian basil belajar siswa pada aspek kognitif dan aspek afektif. Guru mengatakan bahwa hasil belajar siswa dalam aspek kognitif dan aspek afektif pada siklus I masih kurang karena rnasih banvak siswa yang tuntas belajar. Guru berharap agar siswa dapat memperbaikinya pada siklus selanjutnya.

\section{Siklus II}

Pada siklus II dilakukan perbaikan berdasarkan hasil analisis dan refleksi serta tindak lanjut dan siklus I sehingga proses pembelajaran pada siklus II bisa lebih baik. Dalam siklus II guru memulai pertemuan seperti pada siklus I yaitu dengan menjelaskan kompetensi dasar dan indikatoor untuk pokok bahasan yang akan dipelajari. Guru juga memberikan pre test kepada siswa, setelah soal pre test 
kan siswa terlihat tidak banyak berkomentar dan langsung mengerjakannya karena mereka sudah terbiasa seperti pertemuan sebelumnya. Guru juga memberikan semangat pada siswa agar mengerjakan soal pre test dengan sebaikbaiknya sehingga siswa bisa mendapatkan nilai pre test yang lebih tinggi dari siklus I. Lalu guru menjelaskan rencana kegiatan pembelajaran serta langkahlangkah pembelajaran model Group Investigation (GI).

Pada tahap awal dalam pembelajaran model Group Investigation (GI), guru mengidentifikasi topik dan mengatur murid ke dalam kelompok. Setelah itu guru membantu siswa menyiapkan sarana dan prarana. sedangkan siswa tanpa adanya perintah dan guru sudah menempati bangku sesuai dengan kelompoknya. Guru juga menyebutkan sub topik dalam pokok bahasan sehingga tiap kelompok dapat memilih sub topik sesuai denang minatnya. Selanjutnva. guru menjelaskan tugas kelompok beserta tanggung jawabnya dan terus mernotivasi siswa agar melaksanakan tugasnya dengan lebih baik dari pada siklus 1. Guru motivasi siswa dengan cara berjanji akan memberikan tambahan nilai dan hadiah untuk siswa yang aktif. Dari semua langkah-langkah yang telah dilakukan oleh guru di atas, dapat diketahui bahwa siswa terlihat antusias untuk mengikuti pembelajaran model Group Investigation karena mereka sudah mengetahui langkah- langkahnya.

Tahap kedua yaitu tahap merencanakan kerjasama dalam menyelesaikan tugas. Dalam tahap mi. sudah terjadi pembagian kerja secara jelas dan siswa sudah merencanakan kerjasama dengan baik karena mereka yakin jika kerjasarna direncanakan dengan baik maka proses penyelesaian tugas akan lebih cepat.

Selanjutnya pada tahap ke-3 setiap kelompok sudah dapat melaksanakan investigasi dengan baik. Pembagian kerja yang jelas pada setiap kelompok membuat hampir semua siswa aktif dalam diskusi kelompok. Semua siswa dalam tiap kelompok dapat bekerjasama dengan baik dan tidak terlihat ada yang mendominasi.

Pada tahap 4 setiap kelompok membuat laporan akhir yang akan dipresentasikan di depan kelas. Dalam tahap ini terlihat kerjasama yang solid antar siswaa dalam setiap kelompok saat membuat laporan yang akan dipresentasikan di depan kelas. Pada tahap ini guru memeriksa laporan akhir yang dibuat oleh masing-masing kelompok.

Dilanjutkan dengan tahap 5 yaitu masing-masing kelompok mempresentasikan laporannya. Saat mempresentasikan laporannya sudah terlihat kepercayaan diri siswa. Hal itu terjadi karena siswa sudah benar-benar memahami laporannya dan jumlah siswa yang aktif pada kegiatan diskusi siklus II lebih banyak dan pada siklus I.

Sebelum tahap terakhir dilaksanakan, terlebih dahulu guru memberikan post test kepada siswa. Selama post test berlangsung guru menjumlahkan nilai siswa dan masingmasing kelompok. Setelah post test selesai guru mengumumkan hasil penilaian dan memberikan hadiah kepada wakil dan lompok yang mendapatkan nilai tertinggi. Pada tahap terakhir yaitu tahap evaluasi. Guru melakukan evaluasi mengenai proses pembelajaran kooperatif model Group Investigation. Guru menilai bahwa siswa sudah dapat melaksanakan tahap-tahap pembelajaran kooperatif model Group Investigation dengan baik. Guru mengatakan bahwa keaktifan dan kontribusi siswa saat diskusi kelompok sudah baik dibandingkan dengan siklus I.

Pada tahap ini guru juga memberikan kesimpulan tentang semua materi yang telah dipresentasikan oleh siswa terutama materi yang berkaitan dengan pertanyaan siswa. Selain itu, guru memberikan evaluasi pencapaian hasil 
belajar siswa pada aspek kognitif dan aspek afektif. Guru mengatakan bahwa sebagian sar hasil belajar siswa dalam aspek kognitif dan aspek afektif pada siklus 11 dah baik, tetapi masih ada juga siswa yang belum tuntas belajar.

\section{Hasil Belajar Siswa Kelas VII MTs Sayyid Yusuf Setelah Mengikuti Pembelajaran Kooperatif Model Group}

\section{a. Aspek Kognitif}

Nilai rata-rata pre test yang diperoleh pada siklus I sebesar 53,11 sedangkan nilai rata-rata post test sebesar 69.37. Hal itu rnenunjukkan bahwa terjadi peningkatan hasil belajar siswa sebesar 16,26. Dari nilai rata-rata pre test siklus I ketahui bahwa siswa yang mengalarni ketuntasan dalam belajar sebanyak 3 siswa dengan persentase $10 \%$ dan yang belum tuntas dalam belajar sebanyak 27 siswa dengan persentase $90 \%$. Sedangkan dan nilai post test diketahui bahwa siswa yang tuntas belajar sebanyak 17 siswa dengan persentase $56,67 \%$ siswa yang belum tunlas belajar sebanyak 13 siswa dengan persentase $43,33 \%$. Sehingga dapat dilihat bahwa hasil belajar siswa meningkat setelah implementasi pembelajaran kooperatif model Group Investigation.

Pada siklus II hasil belajar siswa dan aspek kognitif juga mengalami ingkatan. Nilai rata-rata pre test siswa sebelum diterapkan pembelajaran mode1 Group Investigation adalah 61,23 dan jumlah siswa yang tuntas belajar sebanyak 11 siswa dengan persentase $36,66 \%$ sedangkan jumlah siswa yang belum tuntas belajar sebanyak 19 siswa dengan persentase 63,33\%. Setelah diterapkan pembelajaran kooperalif model Group Investigation, nilai rata-rata post test siswa meningkat menjadi 81.63 dan jumlah siswa yang tuntas belajar banyak 29 siswa dengan persentase $96,67 \%$ sedangkan siswa yang belurn tuntas belajar sebanyak 1 siswa dengan persentase 3,33\%. Itu berarti bahwa hasil belajar siswa mengalami peningkatan sebesar 20,43.

b. Aspek Afektif

Penilaian hasil belajar ditinjau dan aspek afektif pada siklus 1 ketahui bahwa siswa yang tuntas belajar sebanyak 18 siswa (60\%) sedangkan siswa yang belum tuntas belajar sebanyak 12 siswa $(40 \%)$. Banyaknya siswa yang belum tuntas belajar disebabkan oleh siswa belum sepenuhnya bisa kerjasama dalam kelompoknya, masih banyak siswa yang mendominasi kerja sehingga siswa yang lain banyak yang diam dan hanya menunggu jawaban dan temannya. Kemampuan berkomunikasi siswa juga kurang, hal itu terlihat saat siswa berdiskusi dengan kelompoknya, mengajukan pertanyaan, saran, kritik, tanggapan maupun sanggahan di depan kelas. Tingkat kejujuran siswa pada saat mengerjakan soal tes pada siklus I asih rendah. masih banyak siswa yang bertanya dan bekerjasama dengan mannya ataupun berusaha untuk membuka buku.

Setelah dilakukan perbaikan pada siklus II diketahui siswa yang tuntas belajar sebanyak 29 siswa $(96,67 \%)$ sedangkan siswa yang belum tuntas belajar sebanyak 1 siswa $(3,33 \%)$. Peningkatan hasil belajar siswa aspek afektif ditandai oleh beberapa hal antara lain siswa sudah mampu bekerjasama dalam kelompoknya, sudah terjadi pembagian kerja yang baik, sudah mau menghargai masukan atau pendapat dan teman sekelompoknya, siswa sudah dapat berkomunikasi dengan kalimat yang baik pada saat berdiskusi ngan kelompoknya, mengajukan pertanyaan, saran, kritik ataupun tanggapan di depan kelas. Tingkat kejujuran siswa juga mengalami peningkatan telihat dan percayaan diri siswa saat mengerjakan tes. 
c. Hambatan Yang Muncul Selama Diterapkannya Pembelajaran Kooperatif Model Group Investigation (GI).

- Pada awalnya siswa mengalami kesulitan bekerja dalam kelompok, terutama siswa yang pintar/pandai tidak mau bergabung dengan siswa yang tidak/kurang pandai. Siswa yang merasa dirinya pandai lebih suka belajar dan bekerja sendiri. Siswa terkesan egois, untuk dapat menyatukan siswa dalam kelompok dan bekerja sama guru berusaha memberi penjelasan tentang pentingnya berbagi, bekerja sama, bersahabat tanpa memperhatikan kepintaran atau kemampuan orang lain. Justru siswa yang memiliki kelebihan daripada temantemannya dapat membantunya dengan memberikan penjelasan tentang teori/materi pelajaran yang belum dipahami dan dimengerti.

- Guru dalam menerapkan pembelajaran kooperatif model Group Investigation (GI), pada pokok bahasan sifat dalam perubahan kimia dan fisika, mengalami kesulitan dalam pengelolaan waktu. Guru belum dapat membagi waktu dalam masing-masing kegiatan pembelajaran.

- Guru dalam mendesain pembelajaran kooperatif model Group Investigation (GI), pada pokok bahasan sifat dalam perubahan kimia dan fisika untuk mata pelajaran IPA, pada awalnya masih ragu dan belum terbiasa.

- Siswa belum terbiasa belajar dengan pembelajaran kooperatif model Group Investigation atau masih terbiasa dengan pola pembelajaran lama (ceramah dan tanya jawab) hanya menunggu informasi dan guru tanpa berinisiatif untuk melakukan dakan memperoleh informasi sendiri.
- Kurangnya rasa kepercayaan diri siswa saat diskusi kelas berlangsung. Sebagian besar siswa masih belum berani mengungkapkan ide atau pendapatnya di depan kelas.

- Minimnya sarana dan prasarana yang mendukung proses pembelajaran kooperatif model Group Investigation khususnya literatur. Dalam pembelajaran model Group Investigation membutuhkan banyak literatur untuk menginvestigasi masalah.

\section{KESIMPULAN DAN SARAN Kesimpulan}

Berdasarkan hasil analisis data dan pembahasan, kesimpulan yang diperoleh adalah sebagai berikut:

1. Guru dalam mendesain pembelajaran kooperatif model Group Investigation (GI), pada pokok bahasan sifat dalam perubahan kimia dan fisika untuk mata pelajaran IPA, pada awalnya masih ragu dan belum terbiasa.

2. Guru dalam menerapkan pembelajaran kooperatif model Group Investigation (GI), pada pokok bahasan sifat dalam perubahan kimia dan fisika dengan kerja kelompok. Pada awalnya siswa mengalami kesulitan bekerja dalam kelompok, terutama siswa yang pintar/pandai tidak mau bergabung dengan siswa yang tidak/kurang pandai. Siswa yang merasa dirinya pandai lebih suka belajar dan bekerja sendiri. Siswa terkesan egois, untuk dapat menyatukan siswa dalam kelompok dan bekerja sama guru berusaha memberi penjelasan tentang pentingnya berbagi, bekerja sama, bersahabat tanpa memperhatikan kepintaran atau kemampuan orang lain. Justru siswa yang memiliki kelebihan daripada teman-temannya dapat membantunya dengan memberikan penjelasan tentang 
teori/materi pelajaran yang belum dipahami dan dimengerti.

3. Guru dalam menerapkan pembelajaran kooperatif model Group Investigation (GI), pada pokok bahasan sifat dalam perubahan kimia dan fisika, mengalami kesulitan dalam pengelolaan waktu. Guru belum dapat membagi waktu dalam masingmasing kegiatan pembelajaran. Siswa terlalu melakukan diskusi, sehingga guru tidak sempat merangkum/menyimpulkan materi yang dibahas karena waktunya sudah habis.

4. Kinerja belajar siswa meningkat setelah pembelajaran IPA menggunakan pembelajaran kooperatif model Group Investigation (GI), pada pokok bahasan sifat dalam perubahan kimia dan fisika. Siswa sangat antusias membahas topik dalam diskusi, dan berusaha menjawab dan menemukan informasi tentang topik tersebut. Siswa saling berebut mengemukakan informasi (apa yang mereka ketahui) tentang topik. Setelah dilakukan pembagian tugas kelompok siswa bekerja sesuai dengan tugasnya masing-masing. Ditinjau dari aspek afektif pada siklus 1 diketahui nilai rata-rata siswa sebesar 70,22 meningkat 83,32 menjadi pada siklus 2 , sehingga dapat disimpulkan bahwa terjadi peningkatan kinerja belajar siswa sebesar 13,1. Siswa yang tuntas belajar pada siklus 1 sebanyak 18 siswa dan siswa yang belum tuntas belajar sebanyak 12 siswa. Sedangkan pada siklus 2 Siswa yang tuntas belajar sebanyak 29 siswa dan siswa yang belum tuntas belajar sebanyak 1 siswa

5. Prestasi belajar siswa meningkat setelah mengalami pembelajaran kooperatif model Group Investigation (GI), pada pokok bahasan sifat dalam perubahan kimia dan fisika. Pada siklus pertama nilai rata-rata pre test adalah 53,11 sedangkan nilai rata-rata post test adalah 69,37. Hal ini menunjukkan terjadi peningkatan hasil belajar siswa sebesar 16,26. Dari nilai pre test diketahui bahwa siswa yang tuntas belajar pada siklus 1 sebanyak 3 siswa (10\%) dan siswa yang belum tuntas belajar sebanyak 27 orang $(90 \%)$. Sedangkan dari nilai post test diketahui bahwa siswa yang tuntas belajar sebanyak 17 siswa $(56,67 \%)$ dan siswa yang belum tuntas sebanyak 13 siswa (43,33\%). Pada siklus 2 nilai rata-rata pre test adalah 61,23 sedangkan nilai rata-rata post test adalah 81,63. Hal ini menunjukkan terjadi peningkatan hasil belajar siswa sebesar 20,4. Dari nilai pre test diketahui bahwa siswa yang tuntas belajar pada siklus 2 sebanyak 11 siswa $(36,66 \%)$ dan siswa yang belum tuntas belajar sebanyak 19 orang (63,33\%). Sedangkan dari nilai post test diketahui bahwa siswa yang tuntas belajar sebanyak 29 siswa $(96,67 \%)$ dan siswa yang belum tuntas sebanyak 1 siswa (3,33\%). Berdasarkan nilai yang diperoleh siswa dapat disimpulkan bahwa pembelajaran kooperatif model Group Investigation (GI), dapat digunakan pada penelitian tindakan kelas.

6. Penelitian tindakan kelas yang dilakukan bertujuan adalah memperbaiki pembelajaran yang dilaksanakan guru. Menggunakan pembelajaran kooperatif model Group Investigation (GI), dapat dijadikan alternatif untuk penelitian tindakan kelas yang akan dilaksanakan berikutnya.

\section{Saran}

Penerapan pembelajaran kooperatif model Group Investigation (GI), memerlukan kemauan dan pengorbanan 
yang besar, baik waktu, tenaga dan pikiran bagi guru untuk mampu melaksanakan penelitian tindakan kelas menggunakan model pembelajaran ini sebagai suatu tantangan.

Penelitian tindakan kelas sebaiknya dilakukan oleh guru dengan penuh kesadaran dan tanggung jawabnya sebagai pendidik, peneliti hanya berusaha menjembatani dan memfasilitasi agar para guru bidang studi IPA khususnya mau melakukan penelitian tindakan kelas sebagai langkah introspeksi diri sebagai tenaga profesional.

Sebaiknya penelitian tindakan kelas dilakukan oleh semua guru, baik guru SD, SMP, maupun SMA, sebagai upaya untuk meningkatkan kinerja sebagai guru. Guru harus dapat menilai dirinya sendiri sebelum melakukan penilaian kepada siswanya. Guru harus mengetahui kelemahan dan kekurangannya dalam pembelajarannya, berusaha untuk mengatasinya dan menemukan solusi yang terbaik serta mengantisipasi apabila dalam pembelajaran mengalami kendala dan masalah.

\section{DAFTAR PUSTAKA}

Abdullah. 2008. Prestasi Belajar, (online), (http://spesialistorch.com/content/view/120/29/), diakses 5 Agustus 2013

Arikunto, dkk. 2007. Penelitian Tindakan Kelas. Jakarta: PT Bumi Aksara.

Arikunto, S. 2006. Prosedur Penelitian. Jakarta: Rineka Cipta.

Dimyati dan Mudjiono. 2002. Belajar dan Pembelajaran. Jakarta: Rineka Cipta.

Hamalik, O. 2004. Proses Belajar Mengajar. Jakarta: PT Bumi Aksara.

Ibrahim, dkk. 2000. Pembelajaran Kooperatif. Surabaya: UNESA_University Press.

Kunandar. 2008. Langkah Mudah PTK Sebagai Pengembangan Profesi Guru. Jakarta: PT Raja Grafindo Persada.
Mulyasa. 2005. Menjadi Guru Profesional Menciptakan Pembelajaran Kreatif dan Menyenangkan. Bandung : Remaja Rosdakarya

Nurhadi, dkk. 2004. Pembelajaran Konstektual Dan Penerapannya Dalam KBK. Malang: Universitas Negeri Malang.

Sagala. 2003. Konsep Dan Makna Pembelajaran. Bandung: Alfabeta.

Slameto. 2003. Belajar Dan FaktorFaktor Yang Mempengaruhinya. Jakarta: Rineka Cipta.

Slavin, R. E. 2008. Cooperative Learning Teori, Riset dan Praktek. Jakarta: Nusamedia

Sugiono. 2005. Memahami Penilaian Kualitatif. Bandung: CV Alfabeta

Sudjana, Dr. Nana. 1997. Media Pengajaran. Bandung: Sinar Baru

Zaini, H. 2007. Strategi Pembelajaran Aktif. Enhacing Teaching and Learning. Yogyakarta: CTSD 
Jurnal Lentera Sains - Prodi Pendidikan IPA

42 Jurnal Lensa, Volume 4 Jilid 2 November 2014 